\title{
Endothelial transcytosis of myeloperoxidase confers specificity to vascular ECM proteins as targets of tyrosine nitration
}

\author{
Stephan Baldus, ${ }^{1,2}$ Jason P. Eiserich, ${ }^{1,2}$ Alireza Mani, ${ }^{3}$ Laura Castro,,${ }^{1,2}$ Mario Figueroa, ${ }^{1,2}$ \\ Phillip Chumley, ${ }^{1,2}$ Wenxin Ma, ${ }^{2,4}$ Albert Tousson, ${ }^{5}$ C. Roger White, ${ }^{2,4}$ Daniel C. Bullard, ${ }^{6}$ \\ Marie-Luise Brennan, ${ }^{7}$ Aldons J. Lusis, ${ }^{8}$ Kevin P. Moore, ${ }^{3}$ and Bruce A. Freeman ${ }^{1,2,9}$ \\ ${ }^{1}$ Department of Anesthesiology, and \\ ${ }^{2}$ The Center for Free Radical Biology, University of Alabama at Birmingham, Birmingham, Alabama, USA \\ ${ }^{3}$ Center for Hepatology, Department of Medicine, Royal Free and University College Medical School, London, \\ United Kingdom \\ ${ }^{4}$ Department of Medicine, Vascular Biology and Hypertension Program, and \\ ${ }^{5}$ The UAB Imaging Facility, University of Alabama at Birmingham, Birmingham, Alabama, USA \\ ${ }^{6}$ Department of Genomics and Pathobiology, University of Alabama at Birmingham, Birmingham, Alabama, USA \\ ${ }^{7}$ Department of Cell Biology, Cleveland Clinic Foundation, Cleveland, Ohio, USA \\ ${ }^{8}$ Department of Medicine, University of California at Los Angeles, Los Angeles, California, USA \\ ${ }^{9}$ Department of Biochemistry and Molecular Genetics, University of Alabama at Birmingham, Birmingham, Alabama, USA \\ Address correspondence to: Bruce Freeman, Department of Anesthesiology, 946 Tinsley Harrison Tower, \\ 619 19th Street South, The University of Alabama at Birmingham, Birmingham, Alabama 35233, USA. \\ Phone: (205) 934-4234; Fax: (205) 934-7437; E-mail: bruce.freeman@ccc.uab.edu.
}

Stephan Baldus' present address is: Department of Cardiology, University Hospital Eppendorf, Hamburg, Germany.

Jason P. Eiserich's present address is: Department of Internal Medicine, Division of Nephrology,

University of California at Davis, Davis, California, USA.

Stephan Baldus and Jason P. Eiserich contributed equally to this work.

Received for publication February 26, 2001, and accepted in revised form August 31, 2001.

\begin{abstract}
Nitrotyrosine formation is a hallmark of vascular inflammation, with polymorphonuclear neutrophil-derived (PMN-derived) and monocyte-derived myeloperoxidase (MPO) being shown to catalyze this posttranslational protein modification via oxidation of nitrite $\left(\mathrm{NO}_{2}^{-}\right)$to nitrogen dioxide $\left(\mathrm{NO}_{2}{ }^{\circ}\right)$. Herein, we show that MPO concentrates in the subendothelial matrix of vascular tissues by a transcytotic mechanism and serves as a catalyst of ECM protein tyrosine nitration. Purified MPO and MPO released by intraluminal degranulation of activated human PMNs avidly bound to aortic endothelial cell glycosaminoglycans in both cell monolayer and isolated vessel models. Cell-bound MPO rapidly transcytosed intact endothelium and colocalized abluminally with the ECM protein fibronectin. In the presence of the substrates hydrogen peroxide $\left(\mathrm{H}_{2} \mathrm{O}_{2}\right)$ and $\mathrm{NO}_{2}^{-}$, cell and vessel wall-associated MPO catalyzed nitration of ECM protein tyrosine residues, with fibronectin identified as a major target protein. Both heparin and the low-molecular weight heparin enoxaparin significantly inhibited MPO binding and protein nitrotyrosine $\left(\mathrm{NO}_{2} \mathrm{Tyr}\right)$ formation in both cultured endothelial cells and rat aortic tissues. $\mathrm{MPO}^{-/-}$mice treated with intraperitoneal zymosan had lower hepatic $\mathrm{NO}_{2} \mathrm{Tyr} /$ tyrosine ratios than did zymosan-treated wild-type mice. These data indicate that MPO significantly contributes to $\mathrm{NO}_{2} \mathrm{Tyr}$ formation in vivo. Moreover, transcytosis of MPO, occurring independently of leukocyte emigration, confers specificity to nitration of vascular matrix proteins.
\end{abstract}

J. Clin. Invest. 108:1759-1770 (2001). DOI:10.1172/JCI200112617.

\section{Introduction}

Nitration of free and protein-associated tyrosine residues to 3-nitrotyrosine $\left(\mathrm{NO}_{2} \mathrm{Tyr}\right)$ is considered a hallmark of inflammatory tissue injury and has been detected in multiple species, organ systems, and cell types during both acute and chronic inflammation (1). Nitrotyrosine formation not only is a mechanistically revealing footprint of oxidative injury but is also critically linked to altered protein structure and function during inflammatory conditions. For example, the selec- tive cellular incorporation of $\mathrm{NO}_{2} \mathrm{Tyr}$ into the extreme carboxyl terminus of the cytoskeletal protein $\alpha$-tubulin impaired cell morphology, monolayer barrier function, and distribution of associated motor proteins (2). Also, nitration of Tyr 67 in cytochrome $c$ profoundly affects its redox-related properties (3); nitration of SERCA2a $\mathrm{Ca}^{2+}$ ATPase Tyr 294 and Tyr 295 inhibits the enzyme (4); nitration of Tyr 34 in concert with dityrosine formation accounts for inactivation of human Mn superoxide dismutase in rejecting transplanted kidneys $(5,6)$; and 
finally, nitration of Tyr 161, 164, and 166 reduces surfactant protein A-dependent lipid aggregation (7). The reversibility of $\mathrm{NO}_{2} \mathrm{Tyr}$ formation implies that tyrosine nitration not only represents a marker of reactive nitrogen species formation and loss of protein function but can potentially evoke protein conformational changes that mimic or impact on cell signaling events such as adenylation and tyrosine phoshorylation $(8,9)$.

Despite evidence for the prevalence of this protein modification under inflammatory conditions, the mechanisms underlying tyrosine nitration in vivo remain poorly understood. Presently, $\mathrm{NO}_{2} \mathrm{Tyr}$ formation is most frequently cited as a footprint of peroxynitrite $\left(\mathrm{ONOO}^{-}\right)$formation and reactivity. Peroxynitrite, the product of ${ }^{\circ} \mathrm{NO}$ and $\mathrm{O}_{2}{ }^{--}$reaction, and nitrosoperoxocarbonate $\left(\mathrm{ONOOCO}_{2}{ }^{-}\right)$, the product of $\mathrm{ONOO}^{-}$reaction with $\mathrm{CO}_{2}$, are both recognized oxidizing and nitrating species $(10,11)$.

However, myeloperoxidase (MPO), a heme protein abundantly expressed in polymorphonuclear neutrophils (PMNs) and monocytes, is also a catalyst of $\mathrm{NO}_{2} \mathrm{Tyr}$ formation via nitrite oxidation to the potent nitrating species nitrogen dioxide $\left({ }^{\circ} \mathrm{NO}_{2}\right)(12,13-15)$. In addition, MPO is considered a general index of inflammation, with increased tissue MPO activity thought to reflect neutrophil and monocyte extravasation. Importantly, there is often increased free MPO observed in the plasma of patients during inflammatory conditions $(16,17)$. Thus, the intraluminal release of this highly cationic protein may facilitate electrostatic interactions with the negatively charged endothelial plasma membrane, thereby favoring neutrophilindependent binding of MPO with the vascular intima $(18,19)$. Independently, the endothelium and the subendothelial space have been identified as a predominant site for $\mathrm{NO}_{2} \mathrm{Tyr}$ formation during tissue inflammatory reactions (20-22), suggesting that MPO may catalyze this oxidative protein modification.

Herein, it is demonstrated that MPO significantly contributes to $\mathrm{NO}_{2} \mathrm{Tyr}$ formation in vivo. We identify a novel process of MPO extravasation that occurs independent of neutrophil diapedesis, thus leading to the deposition of MPO within the vascular ECM. From this, a high degree of spatial codistribution of MPO and $\mathrm{NO}_{2}$ Tyr formation occurs, suggesting that this focalization of MPO confers specificity upon ECM proteins as targets of tyrosine nitration. In aggregate, these findings reveal that MPO catalysis provides an important enzymatic pathway for protein tyrosine nitration during vascular inflammation.

\section{Methods}

Materials. Purified MPO derived from human PMNs, xanthine oxidase $(\mathrm{XO})$, rabbit polyclonal antisera against $\mathrm{MPO}$, and rat fibronectin were obtained from Calbiochem Inc. (La Jolla, California, USA). Monoclonal anti-fibronectin (clone E3E) was purchased from Chemicon International (Temecula, California, USA). Heparin (porcine intestinal mucosa) was from Polysciences Inc.
(Warrington, Pennsylvania, USA), enoxaparin from Aventis Pharmaceuticals (Parsippany, New Jersey, USA). Glycosaminoglycan lyases were from Seikagaku Corp. (Tokyo, Japan). Mouse monoclonal anti-3-nitrotyrosine (clone 1A6) and $\mathrm{ONOO}^{-}$were a gift from Joe Beckman and Alvaro Estevez (University of Alabama at Birmingham). Sheep polyclonal anti-rat vWF was from Cedarlane Laboratories Ltd. (Hornby, Ontario, Canada). Secondary fluorescent antibodies Alexa 488 goat anti-rabbit IgG conjugate, Alexa 594 goat anti-mouse IgG conjugate, Alexa 594 donkey anti-sheep IgG conjugate, and 4,6diamino-2-phenylindole (DAPI) were from Molecular Probes Inc. (Eugene, Oregon, USA). Lymphocyte separation medium was obtained from Organon Teknika (Durham, North Carolina, USA), TRITC-labeled dextran $(4,400 \mathrm{Da})$ and zymosan from Sigma Chemical Co. (St. Louis, Missouri, USA), Transwell cell culture inserts from Becton Dickinson and Co. (Franklin Lakes, New Jersey, USA), chambered cell culture slides (Permanox) from Nalge NUNC International (Rochester, New York, USA), gradient gels from Bio-Rad Laboratories (Hercules, California, USA), and enhanced chemiluminescence (Femto SuperSignal) for Western blot analysis from Pierce Chemical Co. (Rockford, Illinois, USA).

MPO activity assay. MPO activity in cell lysates was determined by adding an aliquot of cell lysate to 43 $\mathrm{mM} \mathrm{NaH}_{2} \mathrm{PO}_{4}$ (pH 5.4), $1.2 \mathrm{mM}$ tetramethylbenzidine, and $100 \mu \mathrm{M} \mathrm{H}_{2} \mathrm{O}_{2}$. Absorbance kinetics were assessed spectrophotometrically at $655 \mathrm{~nm}$.

MPO binding studies. Confluent bovine aortic endothelial cells (BAECs; passages 4-9) seeded in 9- $\mathrm{cm}^{2}$ dishes were exposed to MPO (2-13 nM) in HBSS ( $\mathrm{pH} 7.4$ ) for various periods of time. Cells were scraped in lysis buffer $\left(100 \mathrm{mM} \mathrm{NaH} \mathrm{PO}_{4}\right.$ buffer containing $0.01 \%$ Triton $\mathrm{X}-100$ [pH 5.5], aprotinin $\left[10 \mu \mathrm{g} \cdot \mathrm{ml}^{-1}\right]$, leupeptin [10 $\left.\mu \mathrm{g} \cdot \mathrm{ml}^{-1}\right]$, and pepstatin $\left.\mathrm{A}\left[1 \mu \mathrm{g} \cdot \mathrm{ml}^{-1}\right]\right)$. In some cases, cells were trypsinized until completely detached (8 minutes), trypsin inhibitor ( $1 \mathrm{mg}$ trypsin inhibitor $1.8 \mathrm{mg}$ trypsin ${ }^{-1}$ ) added, cells centrifuged for 10 minutes at $400 \mathrm{~g}$, and the pellet resuspended in lysis buffer. In other experiments, BAECs were pretreated with heparin, enoxaparin, or chondroitin sulfate (all $150 \mu \mathrm{g} \cdot \mathrm{ml}^{-1}$ ) for 45 minutes. Cells were washed and exposed to MPO (13 nM) for 2 hours and scraped in lysis buffer before further processing for DNA quantification, MPO activity, and immunoblotting. In some instances, cells were pretreated with heparinase, heparitinase, or chondroitinase (all $8 \mathrm{mU} \cdot \mathrm{ml}^{-1}$ ) for 45 minutes at $37^{\circ} \mathrm{C}$, and then cells were washed and exposed to $\mathrm{MPO}$ at $4^{\circ} \mathrm{C}$ for 2 hours before harvesting in lysis buffer and subsequent DNA content and MPO activity determination. BAECs were also exposed to MPO $\left(13 \mathrm{nM}, 1 \mu \mathrm{g} \cdot \mathrm{ml}^{-1}\right)$ for 2 hours in concert with increasing doses of xanthine oxidase $\left(\mathrm{XO}, 0-100 \mu \mathrm{g} \cdot \mathrm{ml}^{-1}\right)$ that was purified prior to use as described previously (23). Cell protein for Western blotting was quantitated by bicinchoninic acid assay (24) and the DNA content of cell lysates determined as described previously (25). In other experiments, endothelial cells were grown on Transwell filters and then exposed to MPO (13-130 nM) in HBSS 
containing TRITC-labeled dextran $(4,400 \mathrm{Da}, 100 \mu \mathrm{M})$. After 2 hours, MPO activity and TRITC fluorescence (excitation wavelength $557 \mathrm{~nm}$, emission wavelength 576 $\mathrm{nm}$ ) in the basolateral compartment were analyzed.

Localization of protein tyrosine nitration in cultured endothelial cells. BAECs were grown to confluence in chambered slides and exposed to MPO $(13 \mathrm{nM} ; 1 \mu \mathrm{g})$ for 2 hours. In some cases, cell MPO incubation was followed by $\mathrm{NO}_{2}{ }^{-}(100 \mu \mathrm{M})$ and $\mathrm{H}_{2} \mathrm{O}_{2}(50 \mu \mathrm{M})$ exposure prior to fixation and processing for immunocytochemistry. To evaluate the effect of $\mathrm{ONOO}^{-}$, confluent cells were grown in chambered slides and placed on a rocker platform, and $\mathrm{ONOO}^{-}$was infused for $10 \mathrm{~min}$ utes at $10 \mu \mathrm{M} \cdot \mathrm{min}^{-1}$ in PBS ( $\mathrm{pH}$ 7.4) for a cumulative exposure of $100 \mu \mathrm{M} \mathrm{ONOO}^{-}$. Cells were processed for immunohistochemistry as described below.

ECM isolation. ECM-rich fractions were isolated by rinsing cells with HBSS, placing culture dishes on ice, and extracting cell and membrane elements with $0.5 \%$ sodium desoxycholate in $10 \mathrm{mM}$ Tris- $\mathrm{HCl}, 150 \mathrm{mM}$ $\mathrm{NaCl}, \mathrm{pH}$ 8.0. Desoxycholate-resistant ECM was first rinsed with $10 \mathrm{mM}$ Tris ( $\mathrm{pH}$ 8.0) and then harvested by adding $17 \mu \mathrm{l} / \mathrm{cm}^{2}$ reducing buffer $(1 \mathrm{M}$ Tris- $\mathrm{HCl}, \mathrm{pH}$ $6.8,4 \%$ SDS, $10 \% \beta$-mercaptoethanol, $23 \%$ glycerol) and heated to $95^{\circ} \mathrm{C}$. The samples were then sonicated, boiled at $95^{\circ} \mathrm{C}$ for 10 minutes, and processed for Western blotting as described below.

Purified fibronectin Western blot analysis. Soluble human plasma fibronectin and the 30-, 45-, and 70-kDa fragments of fibronectin (all $100 \mu \mathrm{g} \cdot \mathrm{ml}^{-1}$ ) were incubated with $\mathrm{MPO}(26 \mathrm{nM}), \mathrm{H}_{2} \mathrm{O}_{2}(50 \mu \mathrm{M})$, and $\mathrm{NO}_{2}^{-}(100 \mu \mathrm{M})$ for 90 minutes at $37^{\circ} \mathrm{C}$. In some cases, fibronectin was preincubated with enoxaparin $\left(150 \mu \mathrm{g} \cdot \mathrm{ml}^{-1}\right)$ for 45 minutes. Proteins were separated by SDS-PAGE on $7.5 \%$ gels for fibronectin and on $10 \%$ gels for fibronectin fragments.

Cell lysate and ECM fraction Western blot analysis. For MPO detection, cell and ECM proteins were separated by SDS-PAGE on $10 \%$ gels. For fibronectin and $\mathrm{NO}_{2} \mathrm{Tyr}$ detection, proteins of ECM-rich fractions were separated by SDS-PAGE on 4-20\% gradient gels. Loading of equal amounts of ECM proteins was affirmed by Coomassie blue staining. Proteins were transferred to nitrocellulose membranes and incubated in blocking buffer (PBS containing $0.05 \%$ Tween and 3\% nonfat dry milk) overnight. Primary antibody concentrations were: rabbit polyclonal anti-MPO, 1:1,000; rabbit polyclonal anti- $\mathrm{NO}_{2} \mathrm{Tyr}, 1: 1,000$; and mouse monoclonal anti-fibronectin, 1:1,000. Horseradish peroxidase-conjugated goat anti-rabbit IgG was used as secondary antibody $(1: 150,000$ for anti-MPO and antifibronectin, and 1:300,000 for anti- $\mathrm{NO}_{2} \mathrm{Tyr}$ ) followed by enhanced chemiluminescence for detection.

Immunocytochemistry. Cell monolayers were fixed in 4\% paraformaldehyde. Rat aortic segments were embedded in OCT compound, frozen, and fixed in 4\% paraformaldehyde. Following fixation, cell monolayers and tissues were permeabilized using $0.1 \%$ Triton X-100 in PBS and blocked for 2 hours in 10\% goat serum in
PBS. Primary antibody incubations were for 12 hours at $4^{\circ} \mathrm{C}$ in $10 \%$ goat serum at the following dilutions: polyclonal rabbit anti-MPO, 1:500 for cell cultures and 1:100 for tissues; monoclonal mouse anti-fibronectin, 1:300); monoclonal mouse anti-nitrotyrosine, 1:200; and polyclonal rabbit anti-rat fibronectin, 1:200. Experiments with polyclonal rabbit anti-vWF (1:50) were performed in $10 \%$ BSA. Secondary antibodies were Alexa 488-conjugated goat anti-rabbit, Alexa 594-conjugated goat anti-rabbit, Alexa 594-conjugated goat antimouse, and Alexa 594-conjugated goat anti-sheep (all $1: 80)$. Nuclei were stained with DAPI $\left(1 \mu \mathrm{g} \cdot \mathrm{ml}^{-1}\right)$. Images were acquired on a Leitz orthoplan microscope (Leica Inc., Wetzlar, Germany) or a Leica DMIRBE inverted epifluorescence-Nomarski microscope with Leica TCS NT Laser Confocal optics (Leica Inc.).

Human PMN studies. Blood was drawn from healthy human volunteers after written informed consent, and isolation of PMNs was performed as described previously (12). The PMNs were suspended either in PBS containing $\mathrm{MgCl}_{2}(0.5 \mathrm{mM}), \mathrm{CaCl}_{2}(1 \mathrm{mM})$, and glucose $\left(1 \mathrm{mg} \cdot \mathrm{ml}^{-1}\right), \mathrm{pH} 7.4$, or in $100 \%$ autologous serum supplemented with nitrite $(200 \mu \mathrm{M})$. Neutrophils were activated with 12-D-tetradecanoylphorbol-13-acetate (TPA; $\left.50 \mathrm{ng} \cdot \mathrm{ml}^{-1}\right)$ or FMLP $(1 \mu \mathrm{M})$ at the time of instillation into the vessel.

Vascular tissue models. Descending thoracic aorta was excised from rats and adventitial tissue was removed before the vessel was cut into rings measuring 3-4 $\mathrm{mm}$ in diameter. Aortic rings were incubated in HBSS and in some cases pretreated with enoxaparin $\left(150 \mu \mathrm{g} \cdot \mathrm{ml}^{-1}\right)$ for 45 minutes. The rings were washed thoroughly and then exposed to MPO (65 nM) for 90 minutes. In all but the enoxaparin-pretreated rings, MPO was removed, and the rings were washed and finally exposed to hydrogen peroxide $(50 \mu \mathrm{M})$ and $\mathrm{NO}_{2}^{-}(100 \mu \mathrm{M})$ in HBSS for 120 minutes at $37^{\circ} \mathrm{C}$. In additional experiments, thoracic branches and the orifice of the aorta were cauterized and $200 \mu \mathrm{l}$ of buffer containing activated PMNs $\left(2 \times 10^{6}\right.$ PMNs/aorta) was instilled. The aorta was placed in HBSS and kept on a rocker platform at $37^{\circ} \mathrm{C}$ for 4 hours. In some instances, PMNs $\left(2 \times 10^{6} \mathrm{PMNs} /\right.$ aorta $)$ were activated and instilled into rat aorta in $100 \%$ autologous serum containing nitrite $(200 \mu \mathrm{M})$, incubated for 3 hours at $37^{\circ} \mathrm{C}$, and freshly isolated PMNs were instilled into the aortic lumen for 3 hours as described above. The tissue was processed for immunohistochemical analysis of MPO as described above.

MPO-deficient mouse model of inflammation. Gene-targeted MPO-null $\left(\mathrm{MPO}^{-/-}\right)$mutant mice were generated as previously described (26). Both $\mathrm{MPO}^{-/-}$and control mice $\left(\mathrm{MPO}^{+/+}\right)$were from a mixed $129 / \mathrm{Sv} \times$ C57BL/6 background. Mice were treated with zymosan $(5 \mathrm{mg} / \mathrm{ml}$ in isotonic $\mathrm{NaCl})$ boiled at $95^{\circ} \mathrm{C}$ for 30 minutes prior to intraperitoneal injection $(0.25 \mathrm{mg} / \mathrm{g}$ body weight). After 96 hours, mice were anesthetized and the liver was perfused in situ with $\mathrm{NaCl}$ via the portal vein. For quantitative $\mathrm{NO}_{2} \mathrm{Tyr}$ analysis by gas chromatography/mass spectroscopy, 

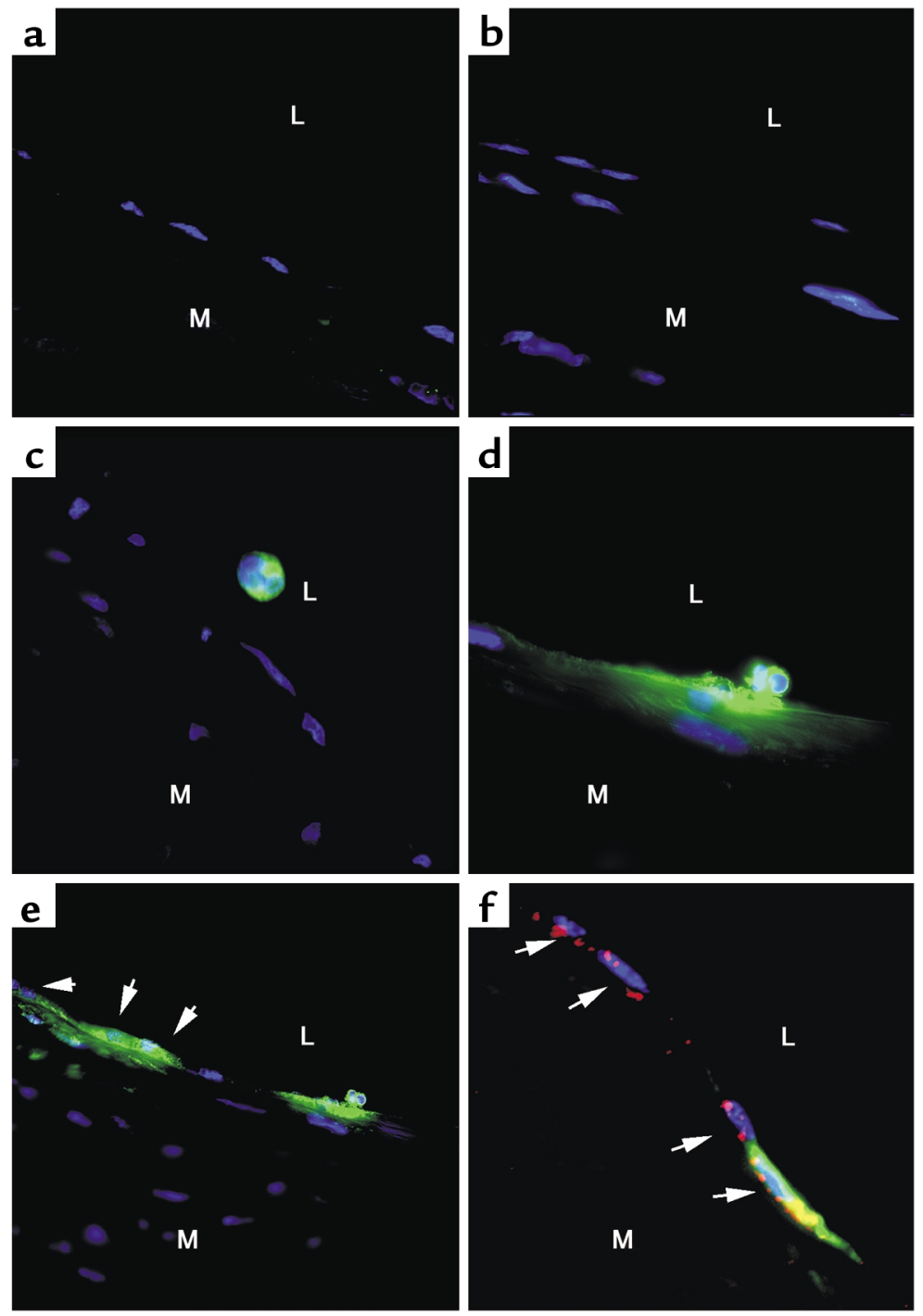

Figure 1

Immunohistochemical detection of aortic endothelial distribution of MPO following activation of PMNs. Isolated human PMNs $\left(8 \times 10^{5}\right)$ were instilled into the lumen of an excised rat aorta immediately after activation with $50 \mathrm{ng} \cdot \mathrm{ml}^{-1}$ TPA. After 4 hours, aortic segments were frozen, sectioned, fixed with $4 \%$ paraformaldehyde, permeabilized using $0.1 \%$ Triton X-100, and analyzed by immunofluorescence. Tissue sections were stained for MPO (green) using rabbit anti-MPO and nuclei (blue) were counterstained with DAPI. (a) Untreated vessel; (b) vessel treated with TPA alone; (c) unstimulated PMNs; (d and e) stimulated PMNs. Colocalization of MPO with anti-vWF immunoreactivity confirmed MPO binding and uptake by endothelial cells $(\mathbf{f})$. L, vessel lumen; $M$, media. Arrows indicate endothelial cells. $\times 100(\mathbf{a}-\mathbf{d}, \mathbf{f}) ; \times 50(\mathbf{e})$.

tissues were flash-frozen in liquid nitrogen, stored at $-80^{\circ} \mathrm{C}$, and further processed as described below.

Quantification of tissue nitrotyrosine content. Nitrotyrosine and tyrosine content in liver proteins was measured by gas chromatography/mass spectrometry as previously described (27). In brief, liver tissue was homogenized in a mixture of saline $(2 \mathrm{ml})$ and chloroform/methanol (2:1) $(13 \mathrm{ml})$ on ice, and the protein precipitate (middle layer) was isolated by centrifugation at $2000 \mathrm{~g}$ for 30 minutes at $4^{\circ} \mathrm{C}$. Following lyophilization of precipitated proteins, $1-1.5 \mathrm{mg}$ of tis- sue was hydrolyzed for 24 hours at $120^{\circ} \mathrm{C}$ in $1 \mathrm{ml} 4 \mathrm{M}$ sodium hydroxide following the addition of $20 \mathrm{ng}{ }^{13} \mathrm{C}_{9}$-nitrotyrosine and $10 \mu \mathrm{g}$ of $\mathrm{D}_{4}$-tyrosine as stable isotopic internal standards. These conditions prevent the nitration of tyrosine that occurs during acidic hydrolysis conditions and permit identification of potential artifactual nitration reactions. Following solid phase extraction, nitrotyrosine and tyrosine were quantitated by gas chromatogra$\mathrm{phy} /$ negative ion chemical ionization mass spectrometry. Results are expressed as a ratio of nitrotyrosine to tyrosine ( $\mathrm{ng} / \mathrm{mg}$ ).

Statistics. All data represent the mean \pm SD. Statistical analyses were performed using ANOVA with Tukey's post hoc analysis on Systat 7.0 software (SPSS Science, Chicago, Illinois, USA). Results with $P<0.05$ were considered significant.

\section{Results}

MPO binding to endothelial cells after PMN degranulation. PMNs are typically viewed as exerting vascular injury after adherence and subsequent diapedesis across the endothelial barrier (28). However, in diverse inflammatory pathologies there is evidence for increased intraluminal degranulation of leukocytes releasing MPO that is accessible to the endothelium $(29,30)$. To evaluate the capacity of PMN-derived MPO to bind to vascular endothelium, rat aortae were exposed to activated human PMNs and tissue sections immunohistochemically analyzed for MPO deposition. Adhesion of MPO-immunoreactive PMNs onto endothelium was affirmed, with the concurrent observation of endothelial cell and the subendothelial compartment distribution of MPO immunoreactivity (Figure 1d) in the absence of attached PMNs (Figure 1e). Control studies analyzing rat aorta (Figure 1a), rat aorta exposed to TPA alone (Figure 1b), and rat aorta incubated with unstimulated neutrophils (Figure 1c) demonstrated no vessel wall MPO immunoreactivity. Stimulation of PMNs with FMLP resulted in an equivalent MPO staining along the vessel lumen (not shown). The localization of MPO immunoreactivity to endothelial cells was confirmed by counterstaining with anti-rat vWF (Figure 1f). These data reveal that MPO penetration into the vascular wall could occur independent of PMN diapedesis.

Uptake and transcytosis of MPO depends on heparin/heparan glycosaminoglycans. The binding of MPO to cultured BAECs was evaluated by exposing BAECs to increasing concentrations of MPO, followed by determination of MPO activity in cell lysates and after digestion of exofa- 


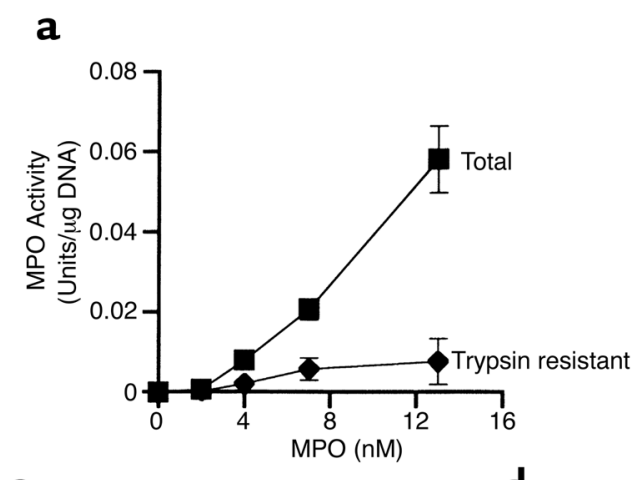

c

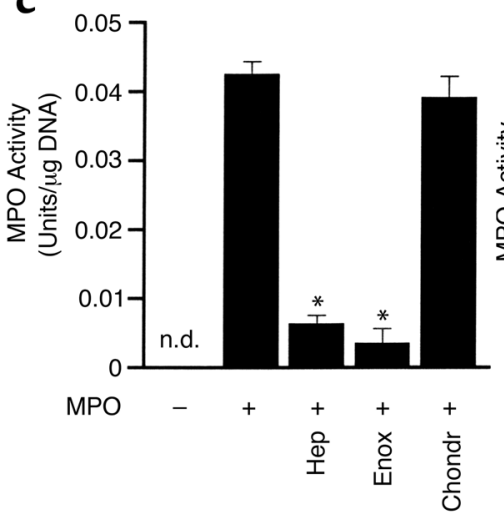

d

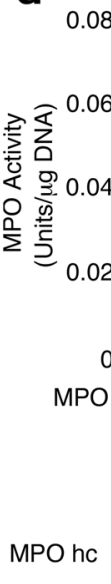

0.087 b

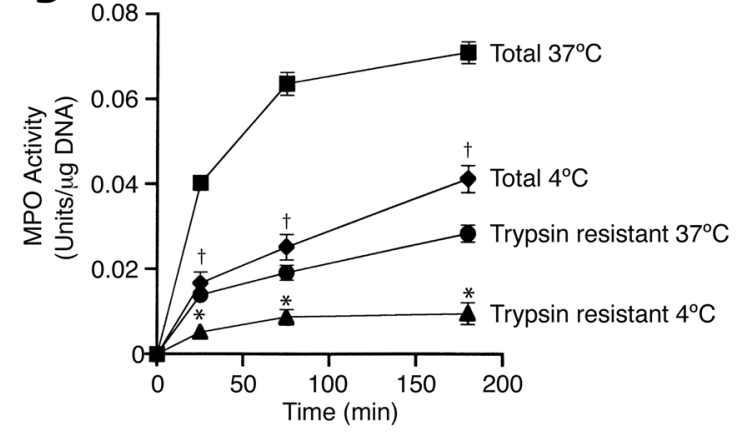

e
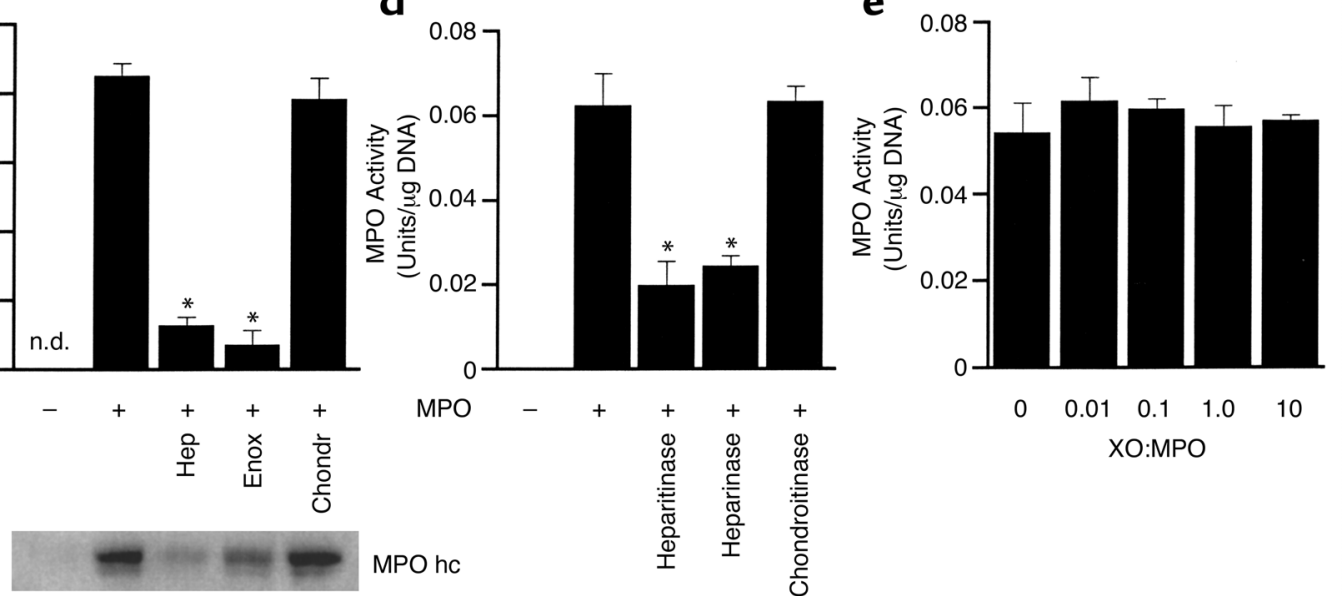

Figure 2

Characterization of the binding and uptake of MPO by cultured endothelial cells. (a) Characterization of cell MPO association. BAECs were incubated with increasing concentrations of MPO (2-13 nM) for 2 hours at $37^{\circ} \mathrm{C}$ and harvested by scraping (total) or after exposure to trypsin (trypsin-resistant). Cell-associated MPO activity was about $10 \%$ of total MPO activity added (not shown). (b) The influence of temperature on cellular MPO binding and transport. BAECs exposed to MPO $(13 \mathrm{nM})$ at $37^{\circ} \mathrm{C}$ and $4^{\circ} \mathrm{C}$ were harvested at different time points and MPO activity was determined. ${ }^{\dagger} P<0.05$ for MPO activity in total cell lysates at $37^{\circ} \mathrm{C}$ versus $4^{\circ} \mathrm{C}$; ${ }^{*} P<0.05$ for MPO activity in trypsinresistant compartments at $37^{\circ} \mathrm{C}$ versus $4^{\circ} \mathrm{C}$. (c) The influence of glycosaminoglycans on cell MPO binding. BAECs were pretreated with chondroitin sulfate $\left(\right.$ Chondr, $\left.150 \mu \mathrm{g} \cdot \mathrm{ml}^{-1}\right)$, heparin $\left(\mathrm{Hep}, 150 \mu \mathrm{g} \cdot \mathrm{ml}^{-1}\right)$, or the low-molecular weight heparin enoxaparin $\left(\right.$ Enox, $\left.150 \mu \mathrm{g} \cdot \mathrm{ml}^{-1}\right)$ for 45 minutes, washed with HBSS, and then exposed to MPO $(13 \mathrm{nM})$ at $37^{\circ} \mathrm{C}$. After washing again, cell-associated MPO was assessed by enzyme activity analysis and cellular MPO protein content by immunoblotting. "MPO hc" denotes the immunoreactivity of the heavy chain $(59 \mathrm{kDa})$ of MPO. (d) The effect of endoglycosidases on MPO binding. BAECs were pretreated with heparitinase, heparinase, and chondroitinase (all $\left.8 \mathrm{mU} \cdot \mathrm{ml}^{-1}\right)$ for 2 hours at $37^{\circ} \mathrm{C}$, washed, and exposed to MPO $(13 \mathrm{nM})$ at $4{ }^{\circ} \mathrm{C}$ for 2 hours. Cell-associated MPO enzyme activity was then determined. ${ }^{*} P<0.05$ for MPO alone versus pretreatment with heparin and enoxaparin (c) and versus heparitinase and heparinase pretreatment $(\mathbf{d})$. (e) Binding competition analysis of MPO and xanthine oxidase (XO). BAECs were incubated with MPO (1 $\left.\mu \mathrm{g} \cdot \mathrm{ml}^{-1}\right)$ and increasing concentrations of XO $\left(0-100 \mu \mathrm{g} \cdot \mathrm{ml}^{-1}\right.$, equivalent to $\left.0-100 \mathrm{mU} \cdot \mathrm{ml}^{-1}\right)$ for 2 hours at $37^{\circ} \mathrm{C}$. Cells were harvested as above and MPO enzyme activity determined. Values represent mean \pm SD.

cial cell proteins with trypsin. The MPO activity of cell lysates increased dose-dependently, and the appearance of MPO activity in a trypsin-resistant compartment suggested intracellular MPO deposition (Figure 2a). In addition, MPO bound to BAECs after degranulation of activated human neutrophils was enzymatically active, and endothelial cell-associated MPO activity was increased to an even greater extent when the respiratory burst of PMNs was inhibited by pretreatment with diphenyliodonium, which prevented the partial inactivation of MPO by PMN-derived oxidants (not shown). To test whether MPO uptake by endothelial cells was energy-dependent, BAECs were exposed to MPO at $4^{\circ} \mathrm{C}$, and trypsin-resistant and total cell-associated MPO activity was determined (Figure 2b). Trypsin-resistant MPO activity at $4^{\circ} \mathrm{C}$ was reduced by more than $80 \%$, suggesting energydependent internalization of the enzyme. The fact that total MPO activity was not decreased as much may be a result of enhanced cell surface binding under $4^{\circ} \mathrm{C}$ conditions, as well as a result of cold-induced retraction of the cytoskeleton directly exposing the subendothelial matrix to MPO. To evaluate the nature of MPO binding to cell surface glycosaminoglycans, cells were pretreated with heparin and the low-molecular weight heparin enoxaparin prior to addition of MPO. Cell-associated MPO activity and MPO protein content were significantly reduced, whereas pretreatment with chondroitin sulfate did not significantly alter cell MPO binding (Figure 2c). Enoxaparin, a low-molecular weight heparin, added to cells after MPO exposure reduced cell-associat- 
a

apical

intracellular basolateral
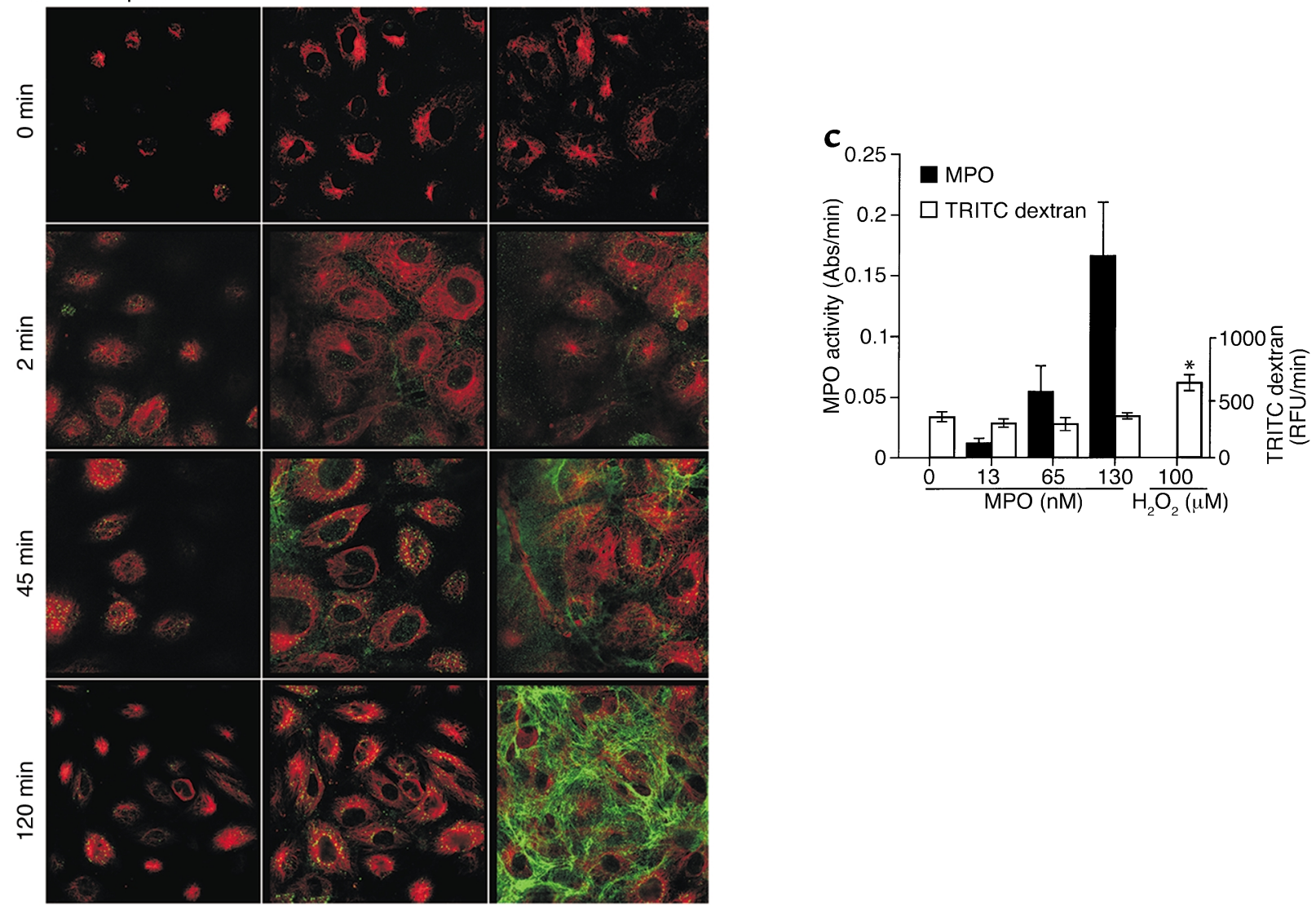

b
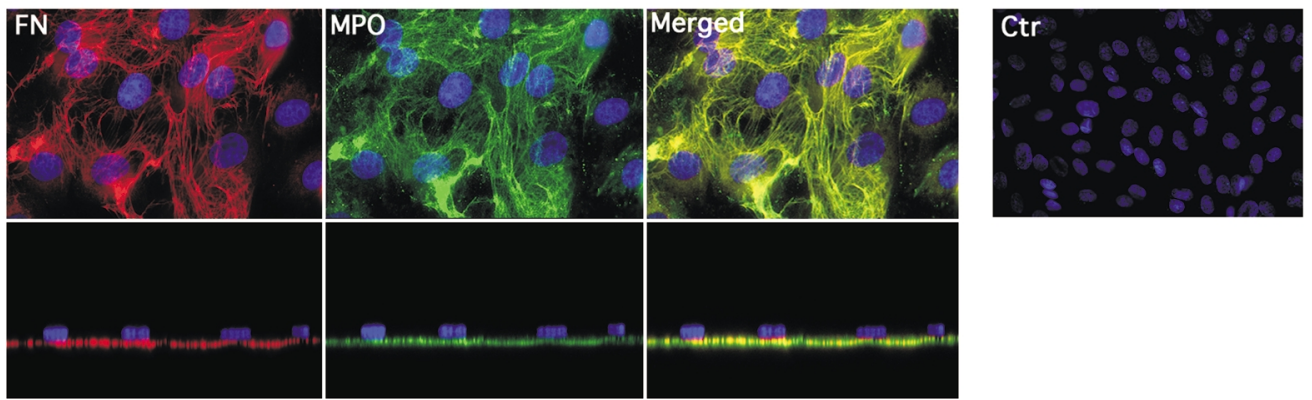

Figure 3

Transcytosis of MPO by endothelial cells. (a) Intracellular localization and accumulation of MPO at the ECM. Cultured BAECs were grown to confluence and exposed to MPO $(13 \mathrm{nM})$ for 2 hours. Cells were processed as described in Methods and incubated with mouse monoclonal anti- $\alpha$-tubulin (red) and rabbit polyclonal anti-MPO (green). Laser confocal microscopy revealed intracellular MPO immunoreactivity within 2 minutes after MPO exposure and a high degree of MPO deposition at the subcellular matrix. Time $=0$ minutes represents BAECs not exposed to MPO but stained with anti-MPO. $\times 63$. (b) Colocalization of MPO and fibronectin (FN). BAECs treated as described for a were incubated with mouse monoclonal anti-fibronectin (red) and rabbit polyclonal anti-MPO (green). The nuclei (blue) were counterstained with DAPI. For assessing codistribution of MPO and fibronectin, images were merged (yellow). The control panel (Ctr) shows MPO-untreated cells stained with antiMPO. The lower panel represents side-on views. $\times 63$ (control, $\times 50$ ). (c) Barrier function of endothelial cell monolayers exposed to MPO. BAECs were seeded on Transwell filters and exposed to increasing concentrations of MPO (13-130 nM) in the presence ofTRITC-labeled dextran (4,400 Da) for 2 hours. MPO activity and TRITC fluorescence were assessed in the basolateral chamber. Treatment of the cells with $\mathrm{H}_{2} \mathrm{O}_{2}(100 \mu \mathrm{M})$ served as a control for increased permeability of TRITC-dextran. ${ }^{*} P>0.05$ versus TRITC-labeled dextran alone. RFU, relative fluorescence units.

ed MPO activity by $78 \% \pm 3 \%$ (not shown). To further characterize the nature of the putative glycosaminoglycan-dependent binding of MPO, BAECs were pretreated with endoglycosidases prior to MPO exposure. Heparitinase or heparinase pretreatment of endothelial cells reduced cell-associated MPO activity by $63 \% \pm 7 \%$ and
$56 \% \pm 8 \%$, respectively, whereas chondroitinase did not significantly inhibit cell association of MPO (Figure 2d). Previous studies have revealed that binding of the $\mathrm{O}_{2}{ }^{\bullet}-$ and $\mathrm{H}_{2} \mathrm{O}_{2}$-generating enzyme xanthine oxidase $(\mathrm{XO})$ to vascular endothelial cells is predominantly chondroitin sulfate-dependent (23). To evaluate the potential bind- 
ing interactions of $\mathrm{MPO}$ and $\mathrm{XO}$, the impact of increasing XO concentrations on endothelial cell MPO binding was determined. Increases in cell-associated MPO activity were not inhibited by $\mathrm{XO}$ concentrations both equaling and exceeding those found in the circulation during pathophysiological events (Figure 2e) (23).

MPO accumulates at the basolateral cell surface and colocalizes with the ECM protein fibronectin. Using laser confocal microscopy we further localized the site of endothelial MPO deposition, by revealing intracellular MPO distribution within minutes after MPO exposure and a strong gradient between apical and basolateral MPO immunoreactivity throughout the ECM after 2 hours (Figure 3a). Here, MPO was demonstrated to colocalize with the ECM protein fibronectin (Figure $3 \mathrm{~b}$ ). Addition of MPO (130 nM) to BAECs in the presence of $100 \%$ human serum led to both intracellular and subendothelial distribution of MPO in the subendothelial matrix (not shown). To test whether MPO influences endothelial cell barrier function, thereby further facilitating its subendothelial accumulation, we exposed endothelial cells grown on transwell filters to increasing doses of MPO in the presence of TRITC-labeled dextran. While MPO activity increased dose-dependently in the basolateral compartment, the transendothelial flux of dextran remained unchanged (Figure $3 \mathrm{c}$ ). In contrast, exposure of BAECs to $\mathrm{H}_{2} \mathrm{O}_{2}(100 \mu \mathrm{M})$ resulted in a significant increase in TRITC-dextran permeability. In concert with demonstrating the energy-dependence of MPO transport (Figure 2b), the cell internalization of MPO the enzyme (Figure 3a), and a diffuse distribution of MPO throughout the subendothelial matrix that was in a diffuse manner not concentrated in cell junctional regions (Figure 3 , $a$ and $b$ ) are all supporting evidence that the mechanism by which MPO traverses endothelial cells is via transcytosis.

Characterization of MPO-dependent nitrotyrosine formation. To define whether the cell matrix distribution of MPO conferred specificity to protein tyrosine nitration, BAECs were exposed to MPO and washed before $\mathrm{NO}_{2}{ }^{-}$ and $\mathrm{H}_{2} \mathrm{O}_{2}$ addition. Following reactions, cells were lysed and the ECM extracted. Western immunoblotting revealed fibronectin immunostaining that correlated with the electrophoretic mobility of the only $\mathrm{NO}_{2} \mathrm{Tyr}-$ immunoreactive species in the ECM protein-rich fraction. In ECM fractions of cells pretreated with enoxaparin, previously demonstrated to inhibit cell and vessel MPO binding/association (Figure 2c), $\mathrm{NO}_{2} \mathrm{Tyr}$ immunoreactivity was profoundly reduced (Figure 4a). MPO also catalyzed $\mathrm{NO}_{2} \mathrm{Tyr}$ formation in soluble human fibronectin exposed to $\mathrm{H}_{2} \mathrm{O}_{2}$ and $\mathrm{NO}_{2}^{-}$, which increased as a function of $\mathrm{NO}_{2}{ }^{-}$concentration as shown by Western blot analysis (Figure $4 \mathrm{~b}$ ). When fibronectin was pretreated with enoxaparin prior to MPO-mediated reactions, fibronectin tyrosine nitration was not reduced, but rather was marginally increased (Figure 4c). The 30-, 45-, and 70-kDa fragments of fibronectin all contain tyrosine residues (31) potentially susceptible to nitration. As for native fibronectin, enoxaparin did not inhibit nitration of fibronectin fragments both encompassing ( $30 \mathrm{kDa}$ and $70 \mathrm{kDa})$ and lacking (45 $\mathrm{kDa}$ ) heparin binding sites (Figure $4 \mathrm{~d}$ ). These observations confirmed that endoglycosidase digestion and heparin (or enoxaparin) treatment inhibited fibronectin

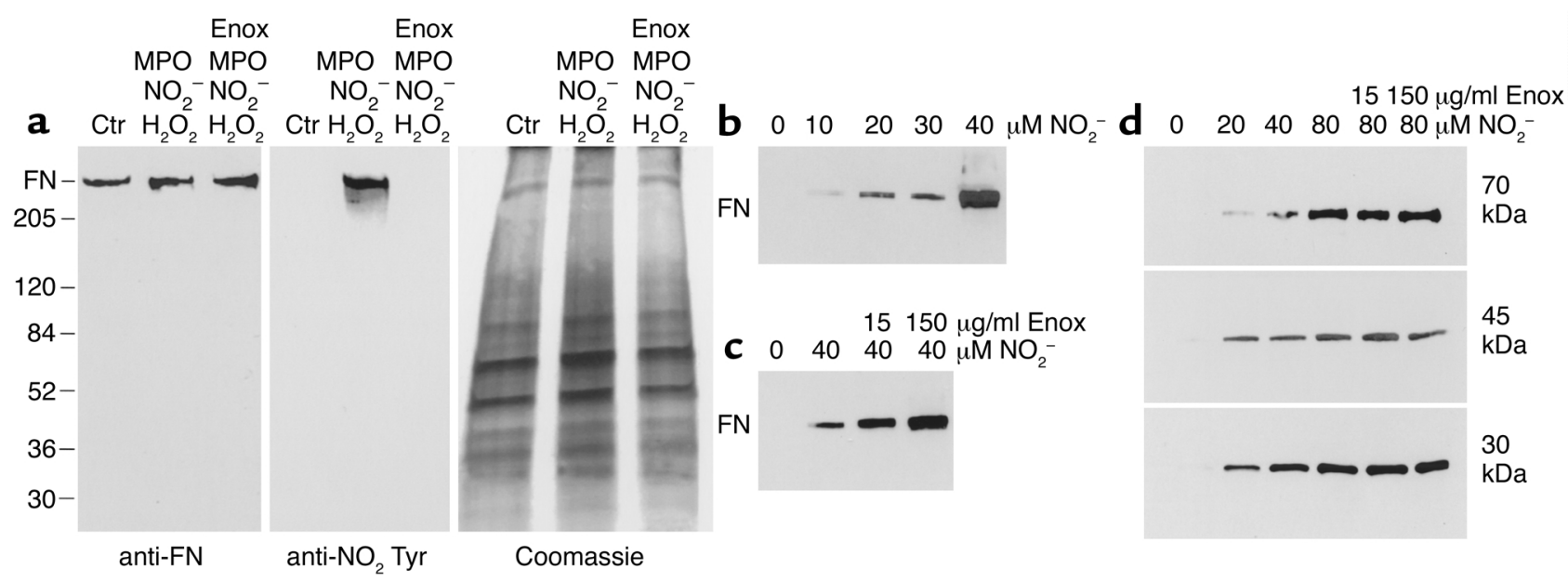

\section{Figure 4}

MPO-dependent tyrosine nitration of ECM fibronectin. (a) $\mathrm{NO}_{2}$ Tyr formation in cultured endothelial cell ECM proteins. Confluent BAEC monolayers were exposed to MPO $(13 \mathrm{nM})$, and washed prior to $\mathrm{NO}_{2}^{-}(100 \mu \mathrm{M})$ and $\mathrm{H}_{2} \mathrm{O}_{2}(50 \mu \mathrm{M})$ addition. In some cases, cells were exposed to enoxaparin (Enox, $150 \mu \mathrm{g} \cdot \mathrm{ml}^{-1}$ ) and washed, followed by MPO exposure and no washing, before $\mathrm{NO}_{2}^{-}$and $\mathrm{H}_{2} \mathrm{O}_{2}$ were added. Matrix-enriched protein fractions were isolated as described in Methods, separated by 4-20\% SDS-PAGE gradient gels, and probed with mouse monoclonal anti-fibronectin and rabbit anti- $\mathrm{NO}_{2} \mathrm{Tyr}$. Protein staining with Coomassie blue confirmed that equal amounts of protein were electrophoretically resolved in each exposure condition. (b-d) $\mathrm{NO}_{2}$ Tyr formation in purified human fibronectin and its major fragments.

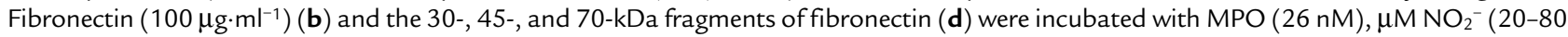
$\mu \mathrm{M})$, and $\mathrm{H}_{2} \mathrm{O}_{2}(50 \mu \mathrm{M})$ in HBSS for 90 minutes. In some cases, fibronectin (c) and fibronectin fragments (d) were preincubated with enoxaparin $\left(15\right.$ and $150 \mu \mathrm{g} \cdot \mathrm{ml}^{-1}$ ) for 45 minutes before $\mathrm{MPO}, \mathrm{NO}_{2}{ }^{-}$, and $\mathrm{H}_{2} \mathrm{O}_{2}$ addition. Proteins were separated by SDS-PAGE electrophoresis (7.5\% gels for fibronectin and $10 \%$ gels for fibronectin fragments) and then immunoblotted with rabbit polyclonal anti- $\mathrm{NO}_{2} \mathrm{Tyr}$. 
a
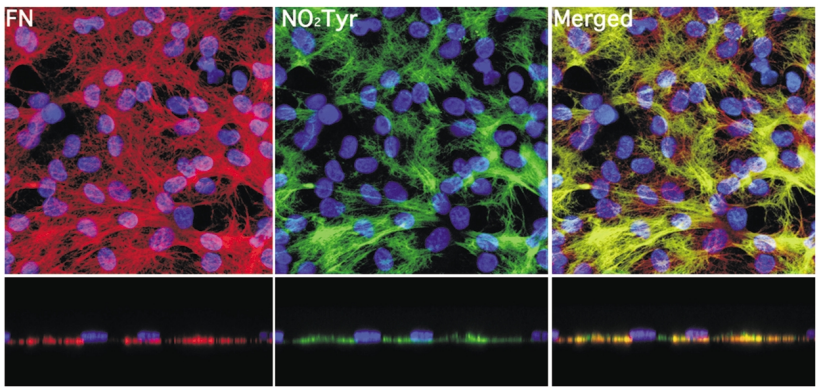

b
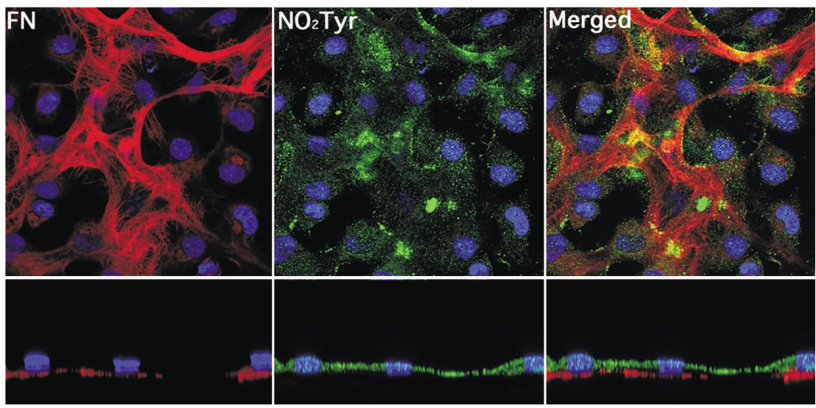

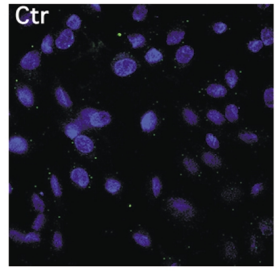

Figure 5

Immunohistochemical distribution of $\mathrm{NO}_{2} \mathrm{Tyr}$ in MPO- and $\mathrm{ONOO}^{-}$-exposed cultured endothelial cells. (a) MPO exposure. BAECs were exposed to MPO (13 $\mathrm{nM})$ for 2 hours and washed, and $\mathrm{NO}_{2}{ }^{-}$ $(100 \mu \mathrm{M})$ and $\mathrm{H}_{2} \mathrm{O}_{2}(50 \mu \mathrm{M})$ were added for 90 minutes. (b) Peroxynitrite exposure. BAECs were exposed to an infusion of $\mathrm{ONOO}^{-}$into culture medium for a final cumulative exposure of $100 \mu \mathrm{M}$. Cells were then fixed in $4 \%$ paraformaldehyde, permeabilized, and immunostained for fibronectin (red) and $\mathrm{NO}_{2} \mathrm{Tyr}$ (green). Nuclei (blue) were counterstained with DAPI. For assessing codistribution of fibronectin and $\mathrm{NO}_{2} \mathrm{Tyr}$, images were merged (yellow). In control experiments, cells were incubated with MPO (13 nM) and $\mathrm{H}_{2} \mathrm{O}_{2}(50 \mu \mathrm{M})$ in the absence of added $\mathrm{NO}_{2}{ }^{-}$, and then immunostained for $\mathrm{NO}_{2}$ Tyr. Image acquisition was performed using laser confocal microscopy, with the lower panel depicting side-on views. $\times 63$. nitration by limiting MPO binding to cells and subsequent transcytosis to the ECM compartment, rather than by inhibition of MPO catalytic nitration activity. To further confirm that fibronectin is the predominant target protein for MPO-catalyzed endothelial cell nitration, BAECs were exposed to MPO, washed, and treated with $\mathrm{H}_{2} \mathrm{O}_{2}$ and $\mathrm{NO}_{2}^{-}$, and then fibronectin and $\mathrm{NO}_{2} \mathrm{Tyr}$ distribution was determined by laser confocal immunocytochemical localization. The strong colocalization of fibronectin and $\mathrm{NO}_{2} \mathrm{Tyr}$ immunoreactivity in the merged images corroborated selective MPO-dependent $\mathrm{NO}_{2}$ Tyr formation in fibronectin (Figure 5a). Moreover, side views indicated that $\mathrm{NO}_{2} \mathrm{Tyr}$ formation was predominantly at the basolateral surface of the cell, further strengthening the concept that the histologic location of MPO will determine principal targets of nitration. In contrast, $\mathrm{ONOO}^{-}$exposure of BAECs resulted in a diffuse cellular pattern of $\mathrm{NO}_{2} \mathrm{Tyr}$ formation (Figure $5 \mathrm{~b}$ ) and lacked the specific pattern characteristic of MPOdependent nitration reactions.

Colocalization of $M P O$ and nitrotyrosine in rat aorta. Rat aortic segments exposed to $\mathrm{MPO}, \mathrm{NO}_{2}^{-}$, and $\mathrm{H}_{2} \mathrm{O}_{2}$ displayed MPO and $\mathrm{NO}_{2}$ Tyr immunoreactivity colocalizing along the endothelium (Figure 6, d-f), further supporting that the MPO-binding microenvironment confers specificity to tyrosine nitration. Adding MPO $(130 \mathrm{nM}), \mathrm{H}_{2} \mathrm{O}_{2}$, and $\mathrm{NO}_{2}^{-}$(both $100 \mu \mathrm{M}$ ) catalyzed tyrosine nitration of BAECs in the presence of $10 \%$ serum and led to equivalent distribution of $\mathrm{NO}_{2} \mathrm{Tyr}$ immunoreactivity in the subendothelial compartment (not shown). Localization of $\mathrm{NO}_{2} \mathrm{Tyr}$ formation in the subendothelium was affirmed by von Willebrand immunoreactivity of adjacent endothelial cells (not shown). When vessel rings were preincubated with enoxaparin, $\mathrm{NO}_{2}$ Tyr immunoreactivity was significantly diminished (Figure 6, g-i), which is in agreement with the reduced $\mathrm{NO}_{2}$ Tyr immunoreactivity observed by Western blot analysis (Figure 4a). Fibronectin immunoreactivity, which predominated along the subendothelium, colocalized with that of $\mathrm{NO}_{2} \mathrm{Tyr}$ (Figure $6, j-1)$ and further confirmed that fibronectin represents a dominant target protein for MPO-catalyzed tyrosine nitration. Rat aortic vessel explants, exposed to activated human neutrophils in $100 \%$ autologous serum containing nitrite $(200 \mu \mathrm{M})$, revealed a similar distribution of MPO deposition along the fibronectinrich sites at the endothelium, which colocalized with $\mathrm{NO}_{2}$ Tyr formation (not shown).

MPO is an important catalyst of vascular $\mathrm{NO}_{2}$ Tyr formation in vivo. To test whether MPO contributes quantitatively to $\mathrm{NO}_{2}$ Tyr formation during tissue inflammatory responses, $\mathrm{MPO}^{-/}$mice and wild-type $\left(\mathrm{MPO}^{+/+}\right)$controls were treated with intraperitoneal zymosan. Whereas the basal liver nitrotyrosine/tyrosine ratios of $\mathrm{MPO}^{+/+}$and $\mathrm{MPO}^{-/-}$animals treated with intraperitoneal sodium chloride were not significantly different $(62 \pm 13$ vs. $60 \pm 11$ ng nitrotyrosine/mg tyrosine, $P>0.05$ ), zymosan-treated $\mathrm{MPO}^{+/+}$ mice displayed a significantly greater nitrotyrosine/tyrosine ratio in liver tissue than did $\mathrm{MPO}^{-/-}$ mice ( $97 \pm 20$ vs. $57 \pm 12 \mathrm{ng}$ nitrotyrosine/mg tyrosine, $P<0.05$; Figure 7$)$.

\section{Discussion}

Both nitric oxide and the heme peroxidase of neutrophils and monocytes, MPO, play central roles in regulating vascular inflammatory responses. Nitric oxide modulates the expression of inflammatory cytokines, adhesion molecules, and enzymes of eicosanoid biosynthesis (32-34). The reactivity of $\bullet \mathrm{NO}$ will also both potentiate and limit oxidative inflammatory injury, depending on the chemical nature and concentrations 
of the participating reactive species: ${ }^{\bullet} \mathrm{NO}$ reacting with $\mathrm{O}_{2}{ }^{\bullet-}$ yields the oxidizing and nitrating species $\mathrm{ONOO}^{-}$ (35), while ${ }^{\bullet} \mathrm{NO}$ also modulates the expression, synthesis, and activity of multiple cellular antioxidant defense mechanisms $(36,37)$. MPO catalyzes the production of the microbicidal species hypochlorous acid $(\mathrm{HOCl})$ and $\mathrm{N}$-chloroamines and is viewed to play a critical role in cell-mediated immunity (38).

Recently, important areas of convergence have been noted for ${ }^{\bullet} \mathrm{NO}$ and $\mathrm{MPO}$ in inflammatory reactions. As shown for other peroxidases, the catalytic activity of MPO is modulated by ${ }^{\bullet} \mathrm{NO}$, an ${ }^{\bullet} \mathrm{NO}$ oxidase reaction that may contribute to altered vascular ${ }^{\circ} \mathrm{NO}$-dependent signaling $(39,40)$. Also, MPO generates a diversity of radical intermediates of low-molecular weight, reducing substrates during its catalytic turnover (e.g., ascorbyl and tyrosyl radicals) that can react with and consume ${ }^{\bullet} \mathrm{NO}$ (41). The present observations have expanded these critical linkages between MPO and ${ }^{\circ} \mathrm{NO}$-mediated signaling and tissue injury mechanisms by revealing that (a) MPO can concentrate at the interface between endothelium and smooth muscle in the absence of PMNs through apical-to-basolateral transcytosis, (b) the association of MPO with interstitial matrix proteins (such as fibronectin) confers specificity to tyrosine nitration reactions, and (c) there is strong histological and biochemical support for the catalysis of protein tyrosine nitration by MPO. This protein modification, a hallmark of inflammatory reactions involving ${ }^{\circ} \mathrm{NO}$ and reactive oxygen species production, is shown not to adhere to the
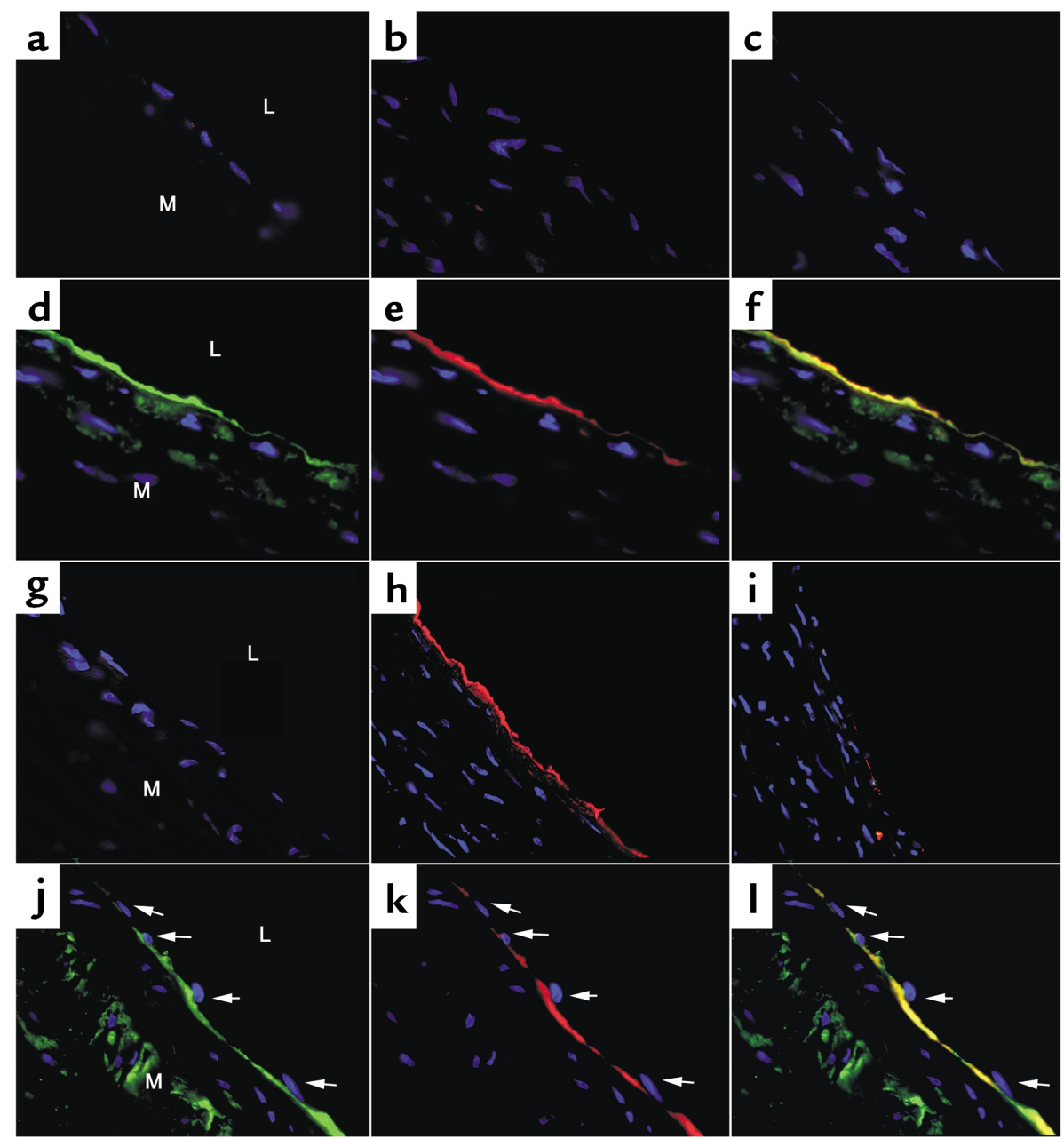

Figure 6

Immunolocalization of MPO, $\mathrm{NO}_{2}$ Tyr, and fibronectin in rat aortic rings. Rat aortic rings were exposed to MPO (65 nM) for 120 minutes, washed, and incubated with $\mathrm{NO}_{2}^{-}(100 \mu \mathrm{M})$ and $\mathrm{H}_{2} \mathrm{O}_{2}(50 \mu \mathrm{M})$ for 90 minutes. In some cases, vessel explants were preincubated with enoxaparin $\left(150 \mu \mathrm{g} \cdot \mathrm{ml}^{-1}\right)$ and washed prior to MPO exposure and omitting the washing step before $\mathrm{H}_{2} \mathrm{O}_{2}$ and $\mathrm{NO}_{2}{ }^{-}$addition. Tissue antigen distribution was visualized using rabbit polyclonal anti-MPO (green), mouse monoclonal anti- $\mathrm{NO}_{2} \mathrm{Tyr}$ (red), and rabbit polyclonal anti-rat fibronectin (green). (a-c) Controls. Untreated vessel segments immunostained for MPO and $\mathrm{NO}_{2} \mathrm{Tyr}(\mathbf{a})$, vessel segments incubated with MPO and stained for $\mathrm{NO}_{2} \mathrm{Tyr}(\mathbf{b})$, and vessel segments treated with $\mathrm{H}_{2} \mathrm{O}_{2}$ and $\mathrm{NO}_{2}$ stained for $\mathrm{NO}_{2} \mathrm{Tyr}(\mathbf{c})$. (d-f) $\mathrm{MPO}$ and $\mathrm{NO}_{2} \mathrm{Tyr}$ distribution. Immunoreactivity for MPO (d) and $\mathrm{NO}_{2} \mathrm{Tyr}(\mathbf{e})$ colocalize, as shown when images were overlaid (f). (g-i) Effect of enoxaparin on $\mathrm{NO}_{2} \mathrm{Tyr}$ formation. Untreated vessel stained for $\mathrm{NO}_{2} \mathrm{Tyr}(\mathbf{g})$, MPO-catalyzed $\mathrm{NO}_{2} \mathrm{Tyr}$ formation $(\mathbf{h})$ was reduced when vessel explants were preincubated with enoxaparin (i). (j-I) Vascular $\mathrm{FN}$ and $\mathrm{NO}_{2}$ Tyr distribution. Subendothelial fibronectin immunoreactivity (j) colocalizes with $\mathrm{NO}_{2} \mathrm{Tyr}$ immunoreactivity $(\mathbf{k})$, as shown in the merged image (I). L, vessel lumen; $M$, media. Arrows indicate endothelial cells. $\times 100(\mathbf{a}-\mathbf{f}, \mathbf{j}-\mathbf{I}) ; \times 50(\mathbf{g}-\mathbf{i})$. 


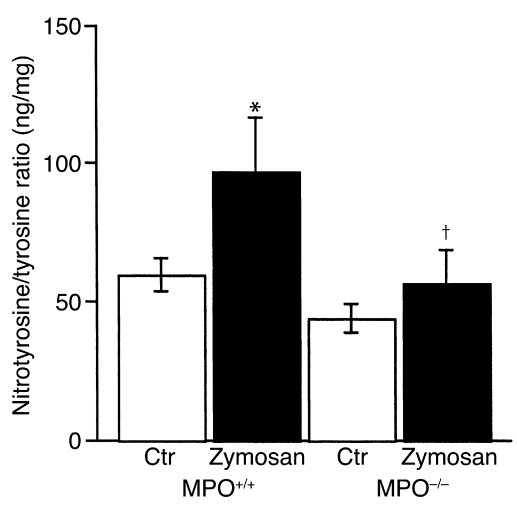

Figure 7

Nitrotyrosine/tyrosine ratio in liver of $\mathrm{MPO}^{-/-}$mice after zymosan treatment. $\mathrm{MPO}^{-/-}$and wild-type mice $\left(\mathrm{MPO}^{+/+}\right)$received either intraperitoneal zymosan $(n=6)$, or sodium chloride $(\mathrm{NaCl})$ as a control $(n=6)$. After 96 hours, the liver was perfused and processed for quantitative nitrotyrosine and tyrosine analysis as described in Methods. ${ }^{\dagger} P<0.05, \mathrm{MPO}^{-/-}$zymosan-treated versus $\mathrm{MPO}^{+/+}$injected with zymosan. ${ }^{*} P<0.05, \mathrm{MPO}^{+/+}$zymosan-treated versus untreated $\mathrm{MPO}^{+/+}$control.

precept that $\mathrm{NO}_{2} \mathrm{Tyr}$ is a specific dosimeter of tissue $\mathrm{ONOO}^{-}$production and reaction, but rather to be a result of PMN degranulation and MPO catalysis.

The selectin- and adhesion molecule-dependent aggregation of PMNs to vascular endothelium is decisive in preceding their egress from the vessel lumen (42). MPO binding to the $\alpha_{\mathrm{M}} \beta_{2}$ integrin of leukocytes and MPO binding to endothelial surface may further support the adherence of PMNs to endothelial cells (43). Moreover, not only does MPO uptake by endothelial cells allow for intracellular oxidant production, but transcytosis of MPO bound to PMNs may reflect an important event in PMN extravasation (44).

MPO is typically presumed to access sites of inflammation upon PMN release of azurophilic granules. The phenomenon of PMN-independent MPO accumulation across the endothelium challenges the view that MPO is a compelling indicator of neutrophil accumulation in tissues (45). Endothelial transcytosis of MPO, a mechanism previously described for other proteins such as IL-8 and lipoprotein lipase $(46,47)$, allows for oxidant formation remote from original sites of degranulation for extended periods of time. This also implies that PMNs may play a more significant causal role in inflammatory signaling and injury processes than previously viewed. This property of MPO can include chronic inflammatory conditions such as atherosclerosis and hypertension that are associated with increased PMN degranulation and tissue MPO activity, despite an apparent lack of elevation in PMN extravasation $(18,19,29,30,48,49)$.

Endothelial cell MPO binding was found to be dependent upon heparin/heparan-containing glycosaminoglycans, since exposing cells to heparin and the low-molecular weight heparin fraction enoxaparin profoundly reduced MPO binding and subsequent cell and vessel tyrosine nitration (Figure 2, $\mathrm{c}$ and d; Figure 4a; and Figure 6, g-i). The inhibition of endothelial MPO binding thus represents an additional mechanism by which heparin analogs exert anti-inflammatory properties (50-52). Interestingly, there was no competition between MPO and the chondroitin sulfate-dependent binding of XO to endothelium (Figure 2e) (23). This results in a provocative scenario of concerted pro-oxidative actions of endothelial and matrix-associated XO and MPO. Given the elevated levels of $\mathrm{XO}$ in the plasma during diverse inflammatory conditions, the ability of $\mathrm{XO}$ to bind to the vessel wall, and $\mathrm{H}_{2} \mathrm{O}_{2}$ production by $\mathrm{XO}, \mathrm{XO}$ may synergize with $\mathrm{MPO}$ to inhibit ${ }^{-N O}$-dependent signaling mechanisms (53-55). For example, $\mathrm{XO}$ could serve as a source of the $\mathrm{H}_{2} \mathrm{O}_{2}$ that facilitates MPO-dependent oxidation, nitration, ${ }^{\circ} \mathrm{NO}$ consumption, and formation of secondary radical species. There are also a diversity of other sources of substrates to support these MPO-catalyzed reactions during inflammation, including the NADPH oxidase of PMNs, cytokine-activated sources of intracellular production of $\mathrm{O}_{2}{ }^{--}$and $\mathrm{H}_{2} \mathrm{O}_{2}$, and the enhanced vascular smooth muscle cell, fibroblast, and endothelial expression of growth factor-inducible homologues of GP-91 phox $(56,57)$. Finally, under inflammatory conditions where intimal concentrations of MPO may occur, there is an increase in plasma and interstitial $\mathrm{NO}_{2}{ }^{-}$concentration to levels often exceeding $30 \mu \mathrm{M}(58)$.

The binding and transcytosis of MPO by endothelial cells provide a defined distribution of MPO adjacent to the vascular lumen. Interestingly, this pattern of MPO deposition closely corresponds to the histological distribution of $\mathrm{NO}_{2} \mathrm{Tyr}(5,20-22)$. Several lines of evidence derived from cell culture and isolated vascular segments also reveal a striking spatial colocalization between MPO deposition and $\mathrm{NO}_{2} \mathrm{Tyr}$ formation (Figure $5 \mathrm{a}$ and Figure $6, \mathrm{~d}-\mathrm{f}$ ). Given that $\mathrm{NO}_{2} \mathrm{Tyr}$ formation has been reported to correlate with MPO activity under various conditions (59-61), these observations indicate that MPO-catalyzed $\mathrm{NO}_{2}$ Tyr formation is a prevalent mechanism in vivo. This is affirmed by the observation that zymosan-treated $\mathrm{MPO}^{-/-}$mice displayed a significant attenuation of inflammatory-induced increases in hepatic nitrotyrosine/tyrosine ratio (Figure 7). Given that neutrophils from mice display only $10-20 \%$ of the MPO content of human neutrophils $(62,63)$, and considering the prevalent occurrence of vessel wall-associated MPO in human disease (e.g., patients with atherosclerotic vascular disease; refs. 18, 19), MPO-catalyzed oxidative and tyrosine nitration reactions are expected to contribute significantly to human pathophysiology. This supposition is reinforced by the observation that leukocyte and blood MPO levels strongly correlate with the presence of coronary artery disease (64). In the context of the present report showing vascular cell binding, transcytosis and matrix deposition of MPO into the interstitial matrix, leukocyte and blood MPO levels will underestimate how extensively tissue is at risk from MPO-derived reactions.

These data challenge the current dogma that $\mathrm{NO}_{2} \mathrm{Tyr}$, although frequently localized in the immedi- 
ate vicinity of neutrophils, is a specific marker for $\mathrm{ONOO}^{-}$production and reactivity (65). Enzymatically catalyzed tyrosine nitration by MPO that is sequestered in defined tissue compartments represents a more controlled and specific process, compared with the diffusion controlled nitration reactions that are observed with $\mathrm{ONOO}^{-}$(66). MPO has also been proposed to catalyze $\mathrm{ONOO}^{-}-$dependent tyrosine nitration (67). This may represent another mechanism linking $\mathrm{NO}_{2} \mathrm{Tyr}$ formation and MPO deposition. The biochemical occurrence and significance of this pathway in vivo remains undefined but, if relevant, still underscores the central role of peroxidases in catalyzing tyrosine nitration.

The ECM protein fibronectin proved to be the predominant protein target for MPO-dependent $\mathrm{NO}_{2} \mathrm{Tyr}$ formation. The impact of heparin and enoxaparin on inhibiting MPO-dependent $\mathrm{NO}_{2} \mathrm{Tyr}$ formation indicates that cell binding and transcytosis of MPO is of pivotal importance for fibronectin tyrosine nitration, a concept supported by the similar inhibitory effect of heparin on MPO-dependent cell protein oxidation (68). In contrast, heparin coincubated directly with fibronectin did not inhibit MPO-dependent nitration (Figure 4, $c$ and d), mirroring in vitro observations that heparin-lipoprotein complex formation did not inhibit MPO-dependent lipid oxidation (69). This supports the view that the predominant nitrating species formed by $\mathrm{MPO},{ }^{\bullet} \mathrm{NO}_{2}$, has a limited diffusion distance and reactivity capable of readily mediating fibronectin nitration in a glycosaminoglycan-containing microenvironment (e.g., the cell matrix). The local formation of both $\cdot \mathrm{NO}_{2}$ and tyrosyl radicals may provide one explanation for the highly specific nitration patterns displayed by MPO; that is, the ability of ${ }^{\bullet} \mathrm{NO}_{2}$ to promote tyrosine nitration is facilitated by simultaneous tyrosyl radical formation, as the reaction between ${ }^{\circ} \mathrm{NO}_{2}$ and tyrosyl radical occurs at a nearly diffusion-limited rate $\left(10^{9}\right.$ $\left.\mathrm{M}^{-1} \mathrm{~s}^{-1}\right)$. Fibronectin critically affects cellular signaling events via integrin and/or growth factor ligation, thereby orchestrating the adherence of neutrophils, as well as the growth and migration of SMC and fibroblasts (70-73). Oxidation and/or nitration of fibronectin has recently been shown to impair fibroblast migration (74). Therefore, "inflamed fibronectin," which has long been associated with actions of PMN-derived or -activated proteases (75), may also be due to oxidative and nitrative modification of fibronectin that results in altered protein function during inflammatory conditions (76).

In summary, MPO is revealed to be an important mediator for $\mathrm{NO}_{2} \mathrm{Tyr}$ formation in vivo. Endothelial transcytosis of MPO resulted in MPO accumulation in the ECM and proved to be elemental for fibronectin nitration that can occur remote from the site of leukocyte degranulation. In addition to serving as a mediator of host defense and oxidative inflammatory tissue injury, $\mathrm{MPO}$ is identified as a $\mathrm{NO}_{2}{ }^{-}$oxidase whose close proximity to specific binding sites such as fibronectin will facilitate and confer specificity to nitration reactions within the vasculature.

\section{Acknowledgments}

This work was supported by grants from the NIH (to B.A. Freeman and C.R. White), the Deutsche Herzstiftung (to S. Baldus), and the Max Planck Gesellschaft (to S. Baldus).

1. Ischiropoulos, H. 1998. Biological tyrosine nitration: a pathophysiological function of nitric oxide and reactive oxygen species. Arch. Biochem. Biophys. 356:1-11.

2. Eiserich, J.P., et al. 1999. Microtubule dysfunction by posttranslational nitrotyrosination of $\alpha$-tubulin: a nitric oxide-dependent mechanism of cellular injury. Proc. Natl. Acad. Sci. USA. 96:6365-6370.

3. Cassina, A.M., et al. 2000. Cytochrome c nitration by peroxynitrite. J. Biol. Chem. 275:21409-21415.

4. Viner, R.I., Ferrington, D.A., Williams, T.D., Bigelow, D.J., and Schoneich, C. 1999. Protein modification during biological aging: selective tyrosine nitration of the SERCA2a isoform of the sarcoplasmic reticulum $\mathrm{Ca}^{2+}$-ATPase in skeletal muscle. Biochem. J. 340:657-669.

5. MacMillan-Crow, L.A., Crow, J.P., Kerby, J.D., Beckman, J.S., and Thompson, J.A. 1996. Nitration and inactivation of manganese superoxide dismutase in chronic rejection of human renal allografts. Proc. Natl. Acad. Sci. USA. 93:11853-11858.

6. Yamakura, F., Taka, H., Fujimura, T., and Murayama K. 1998. Inactivation of human manganese-superoxide dismutase by peroxynitrite is caused by exclusive nitration of tyrosine 34 to 3-nitrotyrosine. J. Biol. Chem. 273:14085-14089.

7. Zhu, S., Basiouny, K.F., Crow, J.P., and Matalon, S. 2000. Carbon dioxide enhances nitration of surfactant protein A by activated alveolar macrophages. Am. J. Physiol. Lung Cell. Mol. Physiol. 278:L1025-L1031.

8. Kamisaki, Y., et al. 1998. An activity in rat tissues that modifies nitrotyrosine-containing proteins. Proc. Natl. Acad. Sci. USA. 95:11584-11589.

9. Berlett, B.S., Levine, R.L., and Stadtman, E.R. 1998. Carbon dioxide stimulates peroxynitrite-mediated nitration of tyrosine residues and inhibits oxidation of methionine residues of glutamine synthetase: both modifications mimic effects of adenylylation. Proc. Natl. Acad. Sci. USA. 95:2784-2789.

10. Beckman, J.S., and Koppenol, W.H. 1996. Nitric oxide, superoxide, and peroxynitrite: the good, the bad, and ugly. Am. J. Physiol. 271:C1424-C1437.

11. Radi, R., Denicola, A., and Freeman, B.A. 1999. Peroxynitrite reactions with carbon dioxide-bicarbonate. Methods Enzymol. 301:353-367.

12. Eiserich, J.P., et al. 1998. Formation of nitric oxide-derived inflammatory oxidants by myeloperoxidase in neutrophils. Nature. 391:393-397.

13. van der Vliet, A., Eiserich, J.P., Halliwell, B., and Cross, C.E. 1997. Formation of reactive nitrogen species during peroxidase-catalyzed oxidation of nitrite. A potential additional mechanism of nitric oxide-dependent toxicity. J. Biol. Chem. 272:7617-7625.

14. Hazen, S.L., et al. 1999. Formation of nitric oxide-derived oxidants by myeloperoxidase in monocytes: pathways for monocyte-mediated protein nitration and lipid peroxidation in vivo. Circ. Res. 85:950-958.

15. van Dalen, C.J., Winterbourn, C.C., Senthilmohan, R., and Kettle, A.J. 2000. Nitrite as a substrate and inhibitor of myeloperoxidase. Implications for nitration and hypochlorous acid production at sites of inflammation. J. Biol. Chem. 275:11638-11644.

16. Biasucci, L.M., et al. 1996. Intracellular neutrophil myeloperoxidase is reduced in unstable angina and acute myocardial infarction, but its reduction is not related to ischemia. J. Am. Coll. Cardiol. 27:611-616.

17. Deby-Dupont, G., Deby, C., and Lamy, M. 1999. Neutrophil myeloperoxidase revisited: its role in health and disease. Intensivmedizin-und-Notfallmedizin. 36:500-513.

18. Daugherty, A., Dunn, J.L., Rateri, D.L., and Heinecke, J.W. 1994. Myeloperoxidase, a catalyst for lipoprotein oxidation, is expressed in human atherosclerotic lesions. J. Clin. Invest. 94:437-444.

19. Malle, E., et al. 2000. Immunohistochemical evidence for the myeloperoxidase/H2O2/halide system in human atherosclerotic lesions: colocalization of myeloperoxidase and hypochlorite-modified proteins. Eur. J. Biochem. 267:4495-4503.

20. Albertini, M., et al. 2000. Role of poly-(ADP-ribose) synthetase in lipopolysaccharide-induced vascular failure and acute lung injury in pigs. J. Crit. Care. 15:73-83.

21. Beckman, J.S., et al. 1994. Extensive nitration of protein tyrosines in human atherosclerosis detected by immunohistochemistry. Biol. Chem. Hoppe Seyler. 375:81-88.

22. Hirabayashi, H., Takizawa, S., Fukuyama, N., Nakazawa, H., and Shinohara, Y. 2000. Nitrotyrosine generation via inducible nitric oxide synthase in vascular wall in focal ischemia-reperfusion. Brain Res. 852:319-325.

23. Houston, M., et al. 1999. Binding of xanthine oxidase to vascular endothelium. Kinetic characterization and oxidative impairment of nitric oxide-dependent signaling. J. Biol. Chem. 274:4985-4994. 
24. Redinbaugh, M.G., and Turley, R.B. 1986. Adaptation of the bicinchoninic acid protein assay for use with microtiter plates and sucrose gradient fractions. Anal. Biochem. 153:267-271.

25. Fiszer-Szafarz, B., Szafarz, D., and Guevara de Murillo, A. 1981. A general, fast, and sensitive micromethod for DNA determination application to rat and mouse liver, rat hepatoma, human leukocytes, chicken fibroblasts, and yeast cells. Anal. Biochem. 110:165-170.

26. Brennan, M.-L., et al. 2001. Increased atherosclerosis in myeloperoxidasedeficient mice. J. Clin. Invest. 107:419-430.

27. Frost, M.T., Halliwell, B., and Moore, K.P. 2000. Analysis of free and protein-bound nitrotyrosine in human plasma by a gas chromatography/mass spectrometry method that avoids nitration artifacts. Biochem. J. 345:453-458.

28. Brown, E. 1997. Neutrophil adhesion and the therapy of inflammation. Semin. Hematol. 34:319-326.

29. Mohacsi, A., Kozlovszky, B., Kiss, I., Seres, I., and Fulop, T. 1996. Neutrophils obtained from obliterative atherosclerotic patients exhibit enhanced resting respiratory burst and increased degranulation in response to various stimuli. Biochim. Biophys. Acta. 1316:210-216.

30. Shen, K., DeLano, F.A., Zweifach, B.W., and Schmid-Schonbein, G.W. 1995. Circulating leukocyte counts, activation, and degranulation in Dahl hypertensive rats. Circ. Res. 76:276-283.

31. Kornblihtt, A.R., Umezawa, K., Vibe-Pedersen, K., and Baralle, F.E. 1985. Primary structure of human fibronectin: differential splicing may generate at least 10 polypeptides from a single gene. EMBO J. 4:1755-1759.

32. Furuke, K., et al. 1999. Human NK cells express endothelial nitric oxide synthase, and nitric oxide protects them from activation-induced cell death by regulating expression of TNF-alpha. J. Immunol. 163:1473-1480.

33. De Caterina, R., et al. 1995. Nitric oxide decreases cytokine-induced endothelial activation. Nitric oxide selectively reduces endothelia expression of adhesion molecules and proinflammatory cytokines. $J$. Clin. Invest. 96:60-68.

34. Salvemini, D., Currie, M.G., and Mollace, V. 1996. Nitric oxide-mediated cyclooxygenase activation. A key event in the antiplatelet effects of nitrovasodilators. J. Clin. Invest. 97:2562-2568.

35. Beckman, J.S., Beckman, T.W., Chen, J., Marshall, P.A., and Freeman, B.A 1990. Apparent hydroxyl radical production by peroxynitrite: implications for endothelial injury from nitric oxide and superoxide. Proc. Natl. Acad. Sci. USA. 87:1620-1624.

36. Darley Usmar, M., Patel, R.P., O’Donell, V.B., and Freeman, B.A. 2000. Antioxidant actions of nitric oxide. In Nitric oxide. Biology and pathobiology. L.J. Ignarro, editor. Academic Press Inc. San Diego, California, USA. 265-276.

37. Deneke, S.M., and Fanburg, B.L. 1989. Regulation of cellular glutathione. Am. J. Physiol. 257:L163-L173.

38. Klebanoff, S.J. 1999. Myeloperoxidase. Proc. Assoc. Am. Physicians. 111:383-389.

39. Glover, R.E., Koshkin, V., Dunford, H.B., and Mason, R.P. 1999. The reaction rates of $\mathrm{NO}$ with horseradish peroxidase compounds I and II. Nitric Oxide. 3:439-444.

40. Abu-Soud, H.M., and Hazen, S.L. 2000. Nitric oxide is a physiological substrate for mammalian peroxidases. J. Biol. Chem. 275:37524-37532.

41. Marquez, L.A., and Dunford, H.B. 1995. Kinetics of oxidation of tyrosine and dityrosine by myeloperoxidase compounds I and II. Implications for lipoprotein peroxidation studies. J. Biol. Chem. 270:30434-30440.

42. Lefer, A.M. 1999. Role of the beta2-integrins and immunoglobulin superfamily members in myocardial ischemia-reperfusion. Ann. Thorac. Surg. 68:1920-1923.

43. Johansson, M.W., Patarroyo, M., Oberg, F., Siegbahn, A., and Nilsson, K. 1997. Myeloperoxidase mediates cell adhesion via the alpha M beta 2 integrin (Mac-1, CD11b/CD18). J. Cell Sci. 110:1133-1139.

44. Yang, J.J., et al. 2001. Internalization of proteinase 3 is concomitant with endothelial cell apoptosis and internalization of myeloperoxidase with generation of intracellular oxidants. Am. J. Pathol. 158:581-592.

45. Matsuo, Y., et al. 1994. Correlation between myeloperoxidase-quantified neutrophil accumulation and ischemic brain injury in the rat. Effects of neutrophil depletion. Stroke. 25:1469-1475.

46. Middleton, J., et al. 1997. Transcytosis and surface presentation of IL-8 by venular endothelial cells. Cell. 91:385-395.

47. Obunike, J.C., et al. 2001. Transcytosis of lipoprotein lipase across cultured endothelial cells requires both heparan sulfate proteoglycans and the very low density lipoprotein receptor. J. Biol. Chem. 276:8934-8941.

48. Shen, K., et al. 1995. Properties of circulating leukocytes in spontaneously hypertensive rats. Biochem. Cell Biol. 73:491-500.
49. Arndt, H., Smith, C.W., and Granger, D.N. 1993. Leukocyte-endothelial cell adhesion in spontaneously hypertensive and normotensive rats. Hypertension. 21:667-673.

50. Park, J.L., et al. 1999. N-acetylheparin pretreatment reduces infarct size in the rabbit. Pharmacology. 58:120-131.

51. Salas, A., et al. 2000. Heparin attenuates TNF-alpha induced inflammatory response through a CD11b dependent mechanism. Gut. 47:88-96.

52. Darien, B.J., et al. 1998. Low molecular weight heparin prevents the pulmonary hemodynamic and pathomorphologic effects of endotoxin in a porcine acute lung injury model. Shock. 9:274-281.

53. White, C.R., et al. 1996. Circulating plasma xanthine oxidase contributes to vascular dysfunction in hypercholesterolemic rabbits. Proc. Natl. Acad. Sci. USA. 93:8745-8749

54. Mugge, A., et al. 1991. Chronic treatment with polyethylene-glycolated superoxide dismutase partially restores endothelium-dependent vascular relaxations in cholesterol-fed rabbits. Circ. Res. 69:1293-1300.

55. Fridovich, I. 1970. Quantitative aspects of the production of superoxide anion radical by milk xanthine oxidase. J. Biol. Chem. 245:4053-4057.

56. Suh, Y.A., et al. 1999. Cell transformation by the superoxide-generating oxidase Mox1. Nature. 401:79-82.

57. Geiszt, M., Kopp, J.B., Varnai, P., and Leto, T.L. 2000. Identification of renox, an $\mathrm{NAD}(\mathrm{P}) \mathrm{H}$ oxidase in kidney. Proc. Natl. Acad. Sci. USA. 97:8010-8014.

58. Torre, D., et al. 1996. Serum concentrations of nitrite in patients with HIV-1 infection. J. Clin. Pathol. 49:574-576.

59. Lamb, N.J., Gutteridge, J.M., Baker, C., Evans, T.W., and Quinlan, G.J. 1999. Oxidative damage to proteins of bronchoalveolar lavage fluid in patients with acute respiratory distress syndrome: evidence for neutrophil-mediated hydroxylation, nitration, and chlorination. Crit. Care Med. 27:1738-1744.

60. Van der Vliet, A., et al. 2000. Myeloperoxidase and protein oxidation in cystic fibrosis. Am. J. Physiol. Lung Cell. Mol. Physiol. 279:L537-L546.

61. Cuzzocrea, S., Costantino, G., Mazzon, E., and Caputi, A.P. 1999. Protective effect of $\mathrm{N}$-acetylcysteine on multiple organ failure induced by zymosan in the rat. Crit. Care Med. 27:1524-1532.

62. Podrez, E.A., Abu-Soud, H., and Hazen, S.L. 2000. Myeloperoxidase-generated oxidants and atherosclerosis. Free Radic. Biol. Med. 28:1717-1725.

63. Rausch, P.G., and Moore, T.G. 1975. Granule enzymes of polymorphonuclear neutrophils: a phylogenetic comparison. Blood. 46:913-919.

64. Zhang, R., et al. 2001. Association between myeloperoxidase levels and risk of coronary artery disease. JAMA. 286:2136-2142.

65. Thom, S.R., Fisher, D., and Manevich, Y. 2001. Roles for platelet-activating factor and ${ }^{*} \mathrm{NO}$-derived oxidants causing neutrophil adherence after CO poisoning. Am. J. Physiol. Heart Circ. Physiol. 281:H923-H930

66. Souza, J.M., Daikhin, E., Yudkoff, M., Raman, C.S, and Ischiropoulos, H. 1999. Factors determining the selectivity of protein tyrosine nitration. Arch. Biochem. Biophys. 371:169-178.

67. Sampson, J.B., Ye, Y., Rosen, H., and Beckman, J.S. 1998. Myeloperoxidase and horseradish peroxidase catalyze tyrosine nitration in proteins from nitrite and hydrogen peroxide. Arch. Biochem. Biophys. 356:207-213.

68. Daphna, E.M., Michaela, S., Eynat, P., Irit, A., and Rimon, S. 1998. Association of myeloperoxidase with heparin: oxidative inactivation of proteins on the surface of endothelial cells by the bound enzyme. Mol. Cell. Biochem. 183:55-61.

69. Upritchard, J.E., and Sutherland, W.H. 1999. Oxidation of heparin-treated low density lipoprotein by peroxidases. Atherosclerosis. 146:211-219.

70. Clark, E.A., King, W.G., Brugge, J.S., Symons, M., and Hynes, R.O. 1998. Integrin-mediated signals regulated by members of the rho family of GTPases. J. Cell Biol. 142:573-586.

71. Hocking, D.C., Sottile, J., and Langenbach, K.J. 2000. Stimulation of integrin-mediated cell contractility by fibronectin polymerization. J. Biol. Chem. 275:10673-10682.

72. Proctor, R.A. 1987. Fibronectin: an enhancer of phagocyte function. Rev Infect. Dis. 4:S412-S419.

73. Magnusson, M.K., and Mosher, D.F. 1998. Fibronectin: structure, assembly, and cardiovascular implications. Arterioscler. Thromb. Vasc. Biol. 18:1363-1370.

74. Sato, E., Koyama, S., Camhi, S.L., Nelson, D.K., and Robbins, R.A. 2001 Reactive oxygen and nitrogen metabolites modulate fibronectin-induced fibroblast migration in vitro. Free Radic. Biol. Med. 30:22-29.

75. Vercellotti, G.M., McCarthy, J., Furcht, L.T., Jacob, H.S., and Moldow, C.F. 1983. Inflamed fibronectin: an altered fibronectin enhances neutrophil adhesion. Blood. 62:1063-1069.

76. Vissers, M.C., and Thomas, C. 1997. Hypochlorous acid disrupts the adhesive properties of subendothelial matrix. Free Radic. Biol. Med. 23:401-411. 